\title{
Early education and the unloved market of commercial child care in Luxembourg
}

Since the late 1990s, the development and qualification of early childhood education in Europe have been directly linked to social investment welfare policies (Esping-Andersen 2002a and b; Lister 2004; OECD 2001). In the wake of the European Union's 'Lisbon process', early childhood and after-school care for children also rapidly expanded in Luxembourg (Hartmann-Hirsch 2009; 2010) and has evolved into an autonomous branch of the Luxembourg educational and social system. Following some rudimentary beginnings in the 1980s (Achten 2012; Achten, Horn and Schronen 2009; Marth and Ramponi 2009), the development of a publicly funded system of extrafamilial childcare was given an initial impulse by the European Employment Initiative of 1997. The present contribution argues that the significance gained by for-profit childcare in Luxembourg's care system has resulted from both effective long-term traditions and singular political decisions (Penn 2011; 2013).

Luxembourg plays no prominent role in international discussions of early childhood education and extrafamilial childcare. Luxembourg is a latecomer, drawing its conceptual inspiration from a transnational diffusion of ideas. The childcare outside of school is traditionally regarded as a private matter, as a family affair. Luxembourg's social model is fundamentally corporatist. In this model, the market is assigned only a marginal role in the production of welfare. Nonetheless for-profit care plays an indispensable role, especially for the age group of up to four years, an age group not yet subject to compulsory education. Without commercial providers, the ever-increasing expansion of childcare in Luxembourg over the past 20 years would not have been possible. How can this be understood? As a mere anomaly and without systematic significance? Or can one learn something from it that might be relevant beyond the borders of Luxembourg?

It is worth observing Luxembourg's 'unloved market of childcare' for at least two reasons. First, because it is a variation of international trends in the marketization of childcare; second, because Luxembourg's case provides reasons for combining care and education into a 'welfare mix', or a 'mixed economy of care'. Interestingly, Luxembourg's for-profit provision is more comparable to the British free-market example than the French and the German welfare state, with which Luxembourg shares more in other respects. 
Methodically, this contribution uses path analysis, but in a rather heuristic way. The concept of 'path dependence' has many forms. Beyer (2006) understands it as a concept of political science that emphasises and examines the fragile stability or stable change ('pathdependent') of institutions. Its appeal lies in enabling us to grasp the unpredictability of social change through the procedural nature of institutions. 'First-order change is a process whereby Instrument settings are changed while the overall goals and instruments of policy remain the same. Second-order change involves altering the instruments of policy as well as their settings, but still leaves the overall policy goals untouched, while third-order change is marked by the radical changes in the overarching terms of policy discourse associated with a paradigm shift' (Scheiwe and Willekens 2009, p. 2). The decisive factors are critical junctures and historical trajectories of incremental adjustment processes (Scheiwe 2009, p. 65). The approach shows similarities to historical institutionalism (Streeck and Thelen 2005; Busemeyer and Nikolai 2010), but without positioning itself systematically in this context.

\section{The context of social welfare policy}

Luxembourg's social model has been shaped after the model of the Bismarckian welfare state (Sozialstaat). ${ }^{1}$ It assigns to the state a dominant, but subsidiary function. Since 1901 , the production of welfare in Luxembourg is based on social security, which funds its incomerelated benefits with equal contributions from workers and employers. Relief is granted depending on demand. Based on Esping-Andersen's known distinction between conservative, social-democratic and liberal welfare regimes (Esping-Andersen 1990), the Luxembourgian social policy researcher Claudia Hartmann-Hirsch (2010) has characterised the Luxembourg welfare state as both family-conservative and corporatist (see also Kerschen 2009). The key figure in social- and family-political terms is the family man in employment. The corporatist model is designed to safeguard one's status; redistribution effects are minimal.

After the Second World War, Luxembourg's social welfare state started to play a social policy role reminiscent of the social-democratic type of welfare regimes, by introducing for example an indexed, guaranteed minimum income. The Luxembourg version of post-war corporatism is characterised by a generally weak 'tertiary sector' and a strong extra-parliamentary-driven consultative mechanism of the social partners (tripartite). Hartmann-Hirsch summarises the characteristics of the Luxembourg welfare model as follows: ' $\ldots$ in the beginning, insurances were launched and enlarged over decades alongside corporatist Bismarckian principles. Scandinavian objectives of high standards and egalitarian protection provided by universal 
schemes developed over the last two decades; liberal elements are marginal, or non-existant [sic]' (Hartmann-Hirsch 2010, p. 7). Since the 1990s, Luxembourg has expanded its extensive and generous benefits as opposed to the general trend towards retrenchment in other EU and OECD countries (Hartmann-Hirsch 2010). The level of social benefits is among the highest in the European Union. The European financial and sovereign debt crisis has resulted in only moderate cuts so far.

This expansion of social transfers and services was made possible due to specificities of Luxembourg's labour market and demographic trends. The Luxembourg-based population, and thus the scope of contributors, grows because of migration. According to the National Statistics Office (Statec) 44,5 per cent of Luxembourg's 537.000 plus residents did not possess Luxembourgian nationality on 1 January 2013 (Institut national de la statistique et des études économiques 2013). The largest group of foreigners are the Portuguese with 16,4 per cent of the resident population. In 2013, the proportion of cross-border commuters (frontaliers) from Belgium, Germany, and France represented 43,6 per cent of the workforce. Only 28,9 per cent of workers in Luxembourg have the Luxembourgian nationality (Inspection générale de la sécurité sociale 2014). With 63,9 per cent, women in employment are just above the EU average (Eurostat 2014). ${ }^{2}$ The transnational labour force counteracts the most important factors of the Western-welfare-state crisis, i.e. population aging and globalisation. Migration and commuting provide Luxembourg's social welfare state with a 'youth bonus', since they contribute significantly to its financing but claim fewer benefits than average (Hartmann-Hirsch 2010).

With the introduction of care insurance and the massive expansion of child day care, two new sectors of personal services have emerged in Luxembourg in the first decade of the twenty-first century. Both types of social benefits relocate care that was previously provided privately in the family into public structures: the institutional and ambulant care for the elderly and the education and day care for the children.

\section{Childcare and preschool education in Luxembourg}

Luxembourg is one of the European countries that provide a publicly organised preschool education for young children. As for other Western European countries, Luxembourg had private day-care schools (Bewahrschulen) by the mid-nineteenth century. The country was then in a long process towards statehood and national independence, which began in 1839 and had not been completed until after the First World War (Pauly 2011). This process took 
place at the intersection of Dutch, Belgian, French, and German influences on all areas of public life; the same applies to the school system and preschool education. Thus, the 1848 Luxembourg Constitution - inspired by the Belgian one - did not grant the Catholic Church the right to establish schools. Compulsory education was introduced in 1861. But only in 1963 all municipalities were required by law to offer preschool education (éducation préscolaire) for the four to six-year-olds (Kneip 2009, p. 710.). This Spillschoul (playschool) was initially a voluntary service that playfully introduced children to learning in school, not dissimilar to the German kindergarten and therefore called jardin d'enfants. Subsequently, attending preschool has become mandatory for five-year-olds (similar to the French écoles maternelles, see Martin and Le Bihan 2009, p 65), extended since 1992 to include four-yearolds - in Germany one would speak of a mandatory kindergarten (Kindergartenpflicht) that assures high rates of pre-primary enrolment. Since 2009, the éducation préscolaire has been part of the cycle un, i.e. the long Luxembourgian primary school (see Beblavy et al. 2011, p. $6 f)$.

This process of integrating preschool education into the school system is part of the differentiation of preschool education and care, a de-mixing of the education and care function of extrafamilial early childhood education. Preschool education has become part of the (all-day) school: compulsory, universal, free, and the duty of the state; whereas childcare at that age remains a private matter and a duty of the families. If the latter cannot perform that duty, children below school age have to be taken proper care of in crèches or by childminders according to their developmental needs. This dual structure determines the relationship between childcare and preschool education in Luxembourg until today, despite all the changes that have occurred since (on the Luxembourg care system from the position of the children, see Honig and Haag 2012).

The Luxembourgian preschool education (éducation préscolaire) differentiates between education and care: it sees the family from the perspective of the school while delegating any extrafamilial care before school age to the care system as exceptional support or emergency assistance. This includes optional, residual provisions which are chargeable and under the responsibility of the Ministry of Family Affairs. Since the care system provides not only for young children, it can also be put to use as an extracurricular service by all school-age children. The foyers scolaires or foyers de jour provide a canteen for lunch and, on weekdays with no afternoon classes, they offer leisure activities and help with homework (Marth and Ramponi 2009, p. 699f). Organisationally, they must conform to the school schedule, and even conceptually their autonomy as an extracurricular educational offer is contested. This 
contribution will, however, deal with extracurricular childcare only to the extent necessary to understand the relationship of preschool education and care as well as its change over time.

In contrast to preschool education, the state of Luxembourg does not take responsibility for day care outside of school, but promotes and accredit private initiative. Back in the nineteenth century, some philanthropic and churchly initiatives had operated childcare facilities for preschoolers without government support. The beginning of an organised extrafamilial early childcare goes back to facilities created by Luxembourg's steel industry for mothers and children of workers, particularly migrants. These play a key role in building the welfare system before the First World War and during the 1920s (Priem and Thyssen 2013). Only since the mid-1970s, the Luxembourg government has supported private initiatives financially. Its most important instrument is the 'convention', a contractual agreement with non-state providers of social services; providers with such an agreement are usually referred to as 'conventionalised' (conventionné). In the 1980s, the state used this instrument especially to support foyers de jour and foyers scolaires, i.e. after-school or school supplementary care. Likewise, a domestic, commercial childcare provided by childminders had existed before this service became part of a public mission. It was given a political-legal framework in 2007 with the law on activité d'assistance parentale (see Mémorial 2007), which also imposed a state accreditation (agrément). The law was legislature's response to an unmanageable, irregular, and partly illegal market of quasi-familial care services.

Today, crèches, garderies, and foyers de jour are the most important collective support facilities before and outside of school (see Willems et al. 2009, p. 689ff); additionally, childminders (assistants parentaux) play a considerable role (Achten, Horn and Schronen 2009 , p. 692). While the crèches care for children up to the age of four during the entire day and throughout the year, foyers de jour take care of school-age children from the age of four to twelve, mainly during lunch hour and as an additional educational support service outside of school and during holidays. Although their use declines, garderies serve children up to eight years of age, who require a supervision of less than 16 hours per week during daytime, a supervision that can be unplanned (Wiltzius and Honig, forthcoming).

\subsection{Structural changes in day care}

The last years of the twentieth century constitute a caesura in Luxembourgian care policy (Haag 2012). The legal foundation of this development was the so-called ASFT Law of 1998 (see Mémorial 1998). It gave a legal basis to the interplay of state and municipalities on the one hand, initiatives and organisations in the social sector on the other. One could say it 
codified the subsidiarity principle of the Luxembourg social welfare state (Achten, Horn and Schronen 2009).

The ASFT Law regulates the relationship between the state and any non-state agencies providing socio-educative, psychosocial, and therapeutic services. It leaves day care providers with an obligatory procedure and an optional enhancement:

- Whoever offers organised day care for children requires an agrément (see Memorial 2001), i.e. an operating licence of the Ministère de l'Éducation nationale, de l'Enfance et de la Jeunesse (MENJE). It regulates safety, hygiene, personnel, infrastructure, qualifications, and the number of children cared for per square metre, thus setting the legal conditions for collective childcare providers or professional childminders to set up their facility.

- The ASFT Law takes up the convention - itself in existence since the 1970 s - to regulate a second, more intensive cooperation between state and non-state providers. If recognised as non-profit, providers of childcare can have some of their operating costs covered by the state on a contractual basis, especially with respect to raising their standards, such as hiring a higher proportion of qualified staff or remunerating staff according to a collective bargaining agreement.

This two-step system of sanctioning and encouraging for-profit day care has created not only the 'conventionalised' sector of care services, but also a 'non-conventionalised' one. These two differ primarily in the degree of state support and regulation. Non-conventionalised providers merely need to comply with the standards necessary for obtaining an operating permit. They are, for example, not bound to the rates of the collective bargaining agreement in the social sector but may pay only the legal minimum wage and thus up to 40 per cent lower salaries. They cannot receive public funds. Non-conventionalised providers are responsible for their running costs, i.e. above all costs linked to their facilities such as rent or reconstructions; personnel costs, e.g. salaries, training, or further education; and any costs linked to the children in care, e.g. meals, care, and toys. They are funded primarily through donations and parental payments. By developing extrafamilial and extracurricular day care, this two-tier system of regulation has rendered possible the emergence of a for-profit care market.

\subsection{Milestones of care policy development}

The ASFT Law and its implementing regulations (règlements grand-ducaux) adopted in later years provide the framework for the development and qualification of day care in Luxembourg after the turn of the twenty-first century. 
A 2005 by-law (see Mémorial 2005) introduced a new type of day-care facility: the maison relais pour enfants (Achten et al. 2009). This new type of care facility was designed as a integrative model for day care in Luxembourg. The maison relais are in many ways similar to the foyers scolaires and the foyers de jour (Ramponi 2009), but they are also meant to accommodate preschoolers. maison relais are intended as a service for all children and as a link between family, school, and municipality (Majerus 2008; 2009). They are optional and subject to costs and are supposed to combine organisational flexibility with educational quality, in other words they connect a range of services for parents with an inclusive care of all children (Honig and Haag 2011, p 18). Children are looked after throughout the year, on five days a week from 6am to 8pm (Achten, Horn und Schronen 2009, p. 693).

The crucial instrument that led to an increased amount of day care for children came in 2009 with the by-law on care vouchers (officially chèque-service accueil; generally abbreviated as chèque-service) (see Mémorial, 2009a). By implementing this chèque-service system, the Luxembourg state sought to reduce the cost of care for parents and thus to promote the use of professional education services (prestations éducatives professionnelles), in particular by households with children that face a higher risk of poverty and social exclusion. At the same time, care vouchers should strengthen their purchasing power (on the systematics of voucher models, see Betz 2010).

The chèque-service accueil is not an aid allowance (allocation de espèce), but a universal allowance in kind (prestation en nature) that is granted to the entire Luxembourg population of children for childcare, or musical and sport activities (Haag 2012, p. 202ff). All children up to the age of 12 who live in Luxembourg are eligible. Depending on their earned income, parents can book a certain amount of hours of care free of charge with a provider of their choice, plus it covers any additional need of care at a reduced rate. Parents are free to choose the setting. ${ }^{3}$ Their own contribution depends on the household income and the number of hours booked. The lowest-income group, i.e. households that receive the guaranteed minimum income, is entitled to 25 hours of free childcare; they pay $€ 0,50$ for any additional and up to 60 hours. The chèque-service accueil is a financial instrument that has almost universalised day care in Luxembourg. Free day care for children has been part of the government programmes since 2009.

Maison relais pour enfants and chèque-service accueil are motivated by the economic and labour market policy decisions of the European Council in Lisbon in 2000 as well as the guidelines on the development of children's day care formulated by the Council two years 
later (2002) at the Barcelona Summit ('Barcelona targets'; Plantenga et al. 2008). With this conceptual model and this funding instrument, the Luxembourg care policy meets the demand for extrafamilial childcare and tries to adapt the care system to the pluralisation of family forms in a multicultural Luxembourg and to the de-standardisation of employment. The maison relais pour enfants follow an integrative basic concept: the move from the principle of extrafamilial childcare to the principle of child-centred education. As a cash benefit linked to extrafamilial care, the chèque-service facilitates the compatibility of family and career.

\section{The growth of extrafamilial day care in Luxembourg}

The instrument of chèque-service has enabled an unprecedented increase in day care for children in Luxembourg that continues to this day. Table 3.1 demonstrates that the number of the chèque-service-billed hours of care between 2009 and 2013 has increased almost threefold.

Table 3.1: Chèque-service-billed hours of care given by collective structures and childminders, 2009$13^{4}$

\begin{tabular}{lccc}
\hline & $\begin{array}{l}\text { Conventionalised sector } \\
\text { (hours) }\end{array}$ & $\begin{array}{l}\text { Non-conventionalised sector } \\
\text { (hours) }\end{array}$ & Total (hours) \\
\hline $\mathbf{2 0 0 9}$ & 9.461 .748 & 4.880 .801 & 14.342 .549 \\
$\mathbf{2 0 1 0}$ & 13.795 .094 & 9.055 .260 & 22.850 .354 \\
$\mathbf{2 0 1 1}$ & 15.914 .830 & 13.295 .424 & 29.210 .254 \\
$\mathbf{2 0 1 2}$ & 17.183 .617 & 18.161 .951 & 35.345 .568 \\
$\mathbf{2 0 1 3}$ & 18.453 .914 & 20.814 .947 & 39.268 .861 \\
\hline
\end{tabular}

Sources: Ministère de la Famille et de l'Intégration (2010, 2011, 2012, 2013); Syndicat Intercommunal de Gestion Informatique (2014)

Looking at the numbers more closely, one is not only impressed by the dynamics and the extent of increase, equally remarkable is the degree to which the development of the conventionalised sector differs from that of the non-conventionalised one. The year the voucher scheme was introduced in the non-conventionalised sector, that sector accounted for only about half as many billed hours of care than the conventionalised sector. Over the following two years the difference decreased rapidly. In 2012 the amount of care given in the non-conventionalised sector exceeded that of the conventionalised one, and in 2013 the difference between the two sectors doubled compared to the previous year. Between 2009 and 2013 , the volume of non-conventionalised day care has more than quadrupled. 
The instrument of chèque-service binds the non-conventionalised sector of day care into cooperation with the state, because all providers that possess an agrément can accept care vouchers. ${ }^{5}$ To them the chèque-service accueil represents an indirect government funding, mediated through the demand of parents and the limited supply of childcare. It was an opportunity quickly taken by the commercial providers. Since 2009, the chèque-service accueil could develop into a central factor of business in the field of childcare; parent's contributions have become an optional source of income. Table 3.1 clearly illustrates that the chèque-service accueil has impacted on the non-conventionalised sector of Luxembourg's care system as an economic stimulus package and thus contributed to putting day care predominantly in the hands of commercial service providers.

In the conventionalised sector, the expansion is driven by the maison relais pour enfants. Since their establishment in 2005, they have quickly become the most important support facility. After having tripled their services between 2005 and 2010 (see Honig and Haag 2011, p. 19), the maison relais increased their supply by roughly another 35 per cent in 2010 , as shown in figure 3.1 .

Figure 3.1: Development of the number of children below the age of four and between four and twelve years in maison relais pour enfants, 2010-13

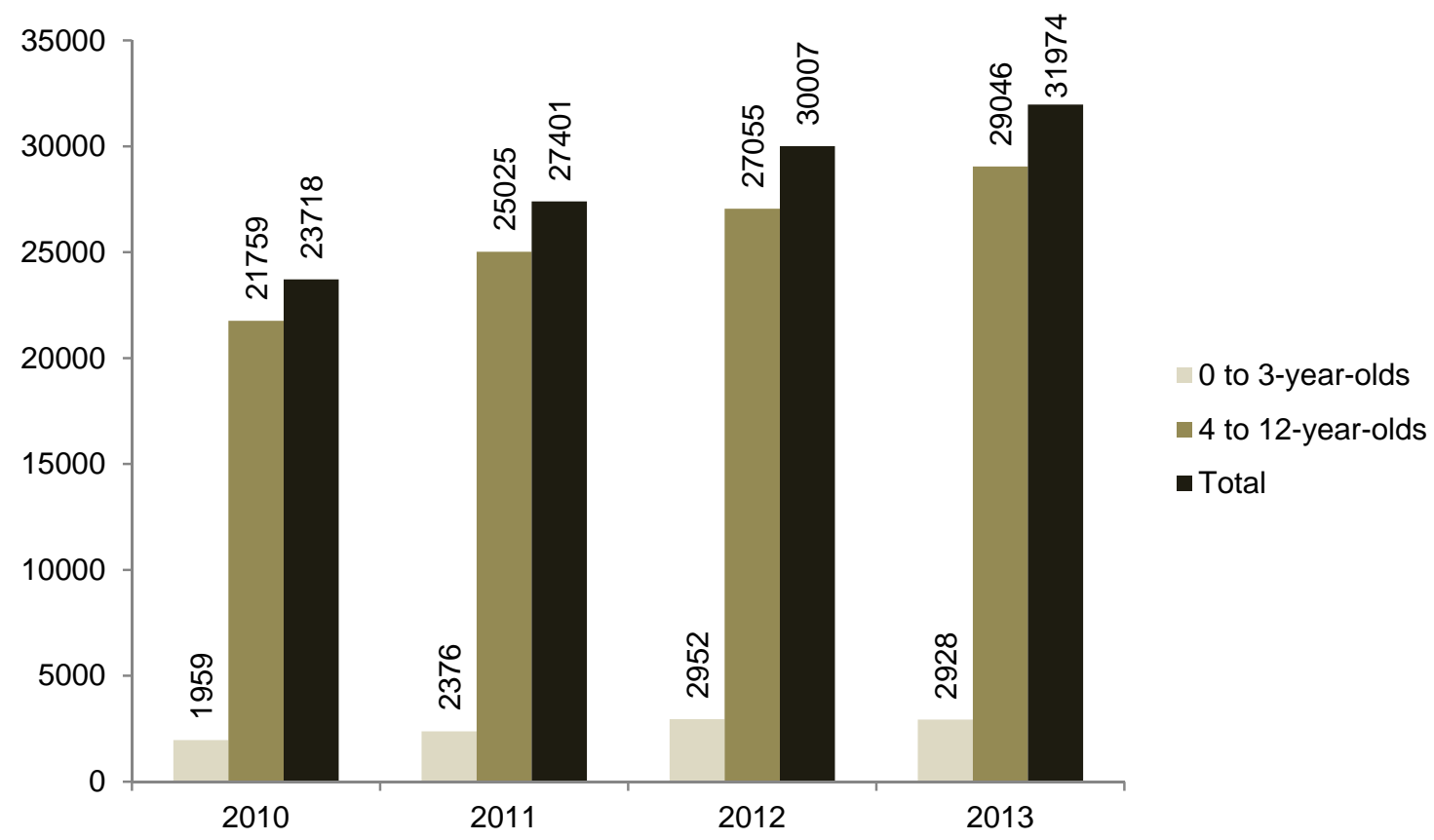

Sources: Ministère de la Famille et de l'Intégration (2011, 2012, 2013, 2014), own illustration

Remarkably, there are major differences between the offer for school children (from four to twelve years) and for preschool children (from zero to three years). In 2013, less than 10 per cent of places in maison relais were for children aged up to three years. This shows that - 
like their predecessors the foyers scolaires - the maison relais are essentially facilities for school children. Has the expansion of the Luxembourg's day care by-passed early childhood?

The answer lies in the non-conventionalised sector of day care. Table 3.2 gives an overview of the entire range of day care for children under the Ministry of Family Affairs (since 2013 Ministry of Education). It includes not only the maison relais in the conventionalised sector, but also non-conventionalised care facilities as well as childminders.

Table 3.2: Development of childcare places by sector and type of care, 2009-13 ${ }^{6}$

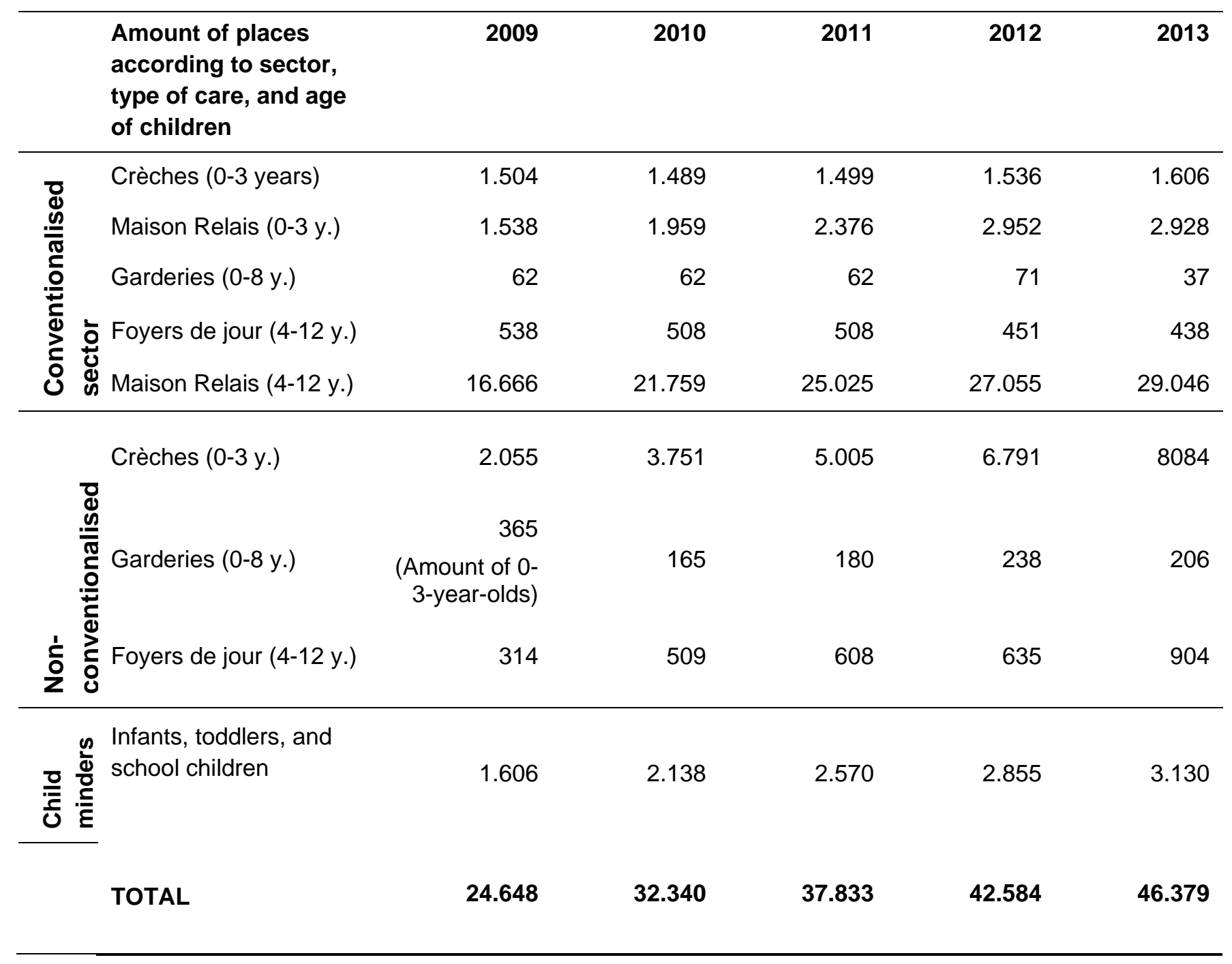

Source: Ministère de la Famille et de l'Intégration (2010, 2011, 2012, 2013, 2014), own illustration

In this overview, we notice the relative weight of the different age groups in childcare: school children clearly are in a majority. On the other hand, the overview also reveals to what extent early childhood care has exploded in both sectors since the introduction of chèque-service 
accueil. This rise in early childhood care really is a new phenomenon. While the increase in the conventionalised sector is around 50 per cent, it has quadrupled in the nonconventionalised sector, where provision for children up to three years of age now form about 64 per cent of all preschool childcare. Before the boom, for-profit day care was more or less respected, but tended to be marginal; in Luxembourg it has now become dominant.

An overview of the number of main childcare centres (without maison relais) within the portfolio of the Ministry of Education (see Table 3.3) shows that the number of nonconventionalised commercial enterprises for preschool children has doubled in recent years and now outnumber the conventionalised crèches six to one.

Tabelle 3.3: Development of facilities by sector and type of care, 2010-13

\begin{tabular}{lrrrrrrrr} 
& \multicolumn{3}{l}{$\begin{array}{l}\text { Non-conventionalised } \\
\text { facilities }\end{array}$} & \multicolumn{7}{c}{$\begin{array}{l}\text { Conventionalised } \\
\text { facilities }\end{array}$} \\
\hline & $\mathbf{2 0 1 0}$ & $\mathbf{2 0 1 1}$ & $\mathbf{2 0 1 2}$ & $\mathbf{2 0 1 3}$ & $\mathbf{2 0 1 0}$ & $\mathbf{2 0 1 1}$ & $\mathbf{2 0 1 2}$ & $\mathbf{2 0 1 3}$ \\
Crèches (0-3 years) & 137 & 174 & 226 & 274 & 47 & 47 & 45 & 45 \\
Garderies (0-8 years) & 11 & 12 & 12 & 10 & 4 & 4 & 4 & 2 \\
$\begin{array}{l}\text { Foyers de jour (4-12 } \\
\text { years) }\end{array}$ & 28 & 36 & 40 & 50 & 20 & 20 & 18 & 18 \\
Total & 176 & 222 & 278 & 334 & 71 & 71 & 67 & 65 \\
\hline
\end{tabular}

Sources: Ministère de la Famille et de l'Intégration (2010, 2011, 2012, 2013, 2014), own illustration

In addition to these collective organisations, different individuals care for children outside or inside the family in return for remuneration (personnes rémunérées), as childminders, babysitters, or domestic helpers. This service does not exist in a conventionalised form and represents a smooth transition to familial or neighbourhood childcare. If one includes these 665 childminders (Ministère de la Famille et de l'Intégration 2014) into the numbers of day care for children below three, the dominant position of for-profit care for this age group is even more pronounced.

In summary, the introduction of care vouchers has moved the weight from publicly funded to privately funded, predominantly commercial childcare. But it has also continued the outmoded division of childcare for preschool and for school children. The care of children up to three years is predominantly in commercial hands, but the amount of publicly funded childcare for this age group - especially in maison relais - has grown considerably. From a path-analytical perspective, care vouchers can be seen as a critical juncture, in which case the earlier findings by Claudia Hartmann-Hirsch would (no longer) be true: the chèque- 
service accueil has given a structural importance to market features within the Luxembourg welfare state.

\section{Marketization in Luxembourg's welfare mix}

The development of childcare in Luxembourg has formally maintained the subsidiary role of the state in organising extrafamilial day care. Schooling is considered a public responsibility, while preschool childcare remains a private concern and is provided by families, non-profit organisations, and commercial enterprises. And yet, it is publicly regulated and - in different ways and to varying degrees - publicly financed.

Within the subsidiarity concept of the Luxembourg social welfare state, the meaning of 'private' is rather enigmatic. On the one hand, it refers to a civic activity that deserves the welfare state's support. Therefore, not only 'private' non-profit, but also 'private' commercial, for-profit providers can be accredited. On the other hand, in common parlance the term privé refers only to the commercial providers of childcare, i.e. all societies or companies not receiving public funding. Non-profit childcare providers are no longer perceived as 'private' when conventionalised and thus entitled to public funds, even though they fall under private law. The care vouchers are, in this sense, not a type of public support, but a social benefit for parents, despite representing de facto the economic basis of a for-profit provision. This ambiguity of the word 'private' calls attention to the fact that, even in a conservative welfare state like Luxembourg, welfare is not solely the responsibility of the state, but is based on the interplay of different actors. One can speak of a specific variant of a welfare mix.

Gøsta Esping-Andersen referred to state, market, and families as the three 'welfare pillars' (Esping-Andersen 2002). This model was extended i.a. by Kaufmann (2003), who added a 'third sector' of the privately funded, non-profit welfare producers. The concept of 'welfare mix' refers to the division of tasks and responsibilities between the state, society, market, and families and their regulating (governance). In this way it tries to avoid a one-sided understanding of welfare production by either the welfare state or the free market. The term is 'an analytical concept that takes into consideration the contributions of the third sector and the informal communal area in welfare production next to those of the state and the market; it stresses particularly the contribution by households and families and especially so in the context of social services' (Evers 2011, p. 279). The concept refers to economic, social and political issues. As a mixed economy of childcare, it emphasizes the socio-economic dimension of the distribution of tasks and responsibilities between the different welfare producers (Evers 2008, p. 43; Lloyd and Penn 2013). In this terminology, the concept is able 
to draw attention to the diverse roles played by the market in the production of welfare, such as the production of care services.

In the context of a free-market-based 'social model', as in the United Kingdom for instance, the state's responsibility for welfare production is seen more narrowly than in the conservative-corporatist model. The boundary between public and private spheres is sharper, and accordingly the differences between non-government welfare producers are greater. It is against this background that Eva Lloyd has distinguished a governance of privatisation from a governance of marketization: 'Privatisation of social welfare and education services may mean the participation of private sector interests in a predominantly publicly funded and delivered service system; it need not necessarily coincide with marketisation, that is the opening up of services to competitive delivery by private providers' (Lloyd 2013, p. 4). Marketization and privatisation appear as opposites. Luxembourg and the United Kingdom would accordingly be incomparable, because, unlike in the United Kingdom, the policy of privatisation in Lloyd's sense has always been an integral element of the Luxembourgian corporatist welfare state.

The United Kingdom is the classic case of an economically liberal welfare system, also linked to a long tradition of private philanthropy (Penn 2009). In the UK care services are traditionally the task of local governments, even though their financing is ensured by the central government and the contributions of parents. Care services traditionally focus on problem groups; poverty is the free-market welfare policy's problem of reference. A nationwide supply of childcare services has existed only since the 1980 s, then accelerated in the 1990s, which is later than in many continental European and Nordic countries, although not quite as late as in Luxembourg.

In the UK, the primacy of for-profit care has been declared policy since the late 1980s (Moss 2009; Penn 2007; 2009; Lewis 2013), not only with respect to day care, but also the education system (see Brehony and Nawrotzki 2011). The marketization of care services promotes competition among private providers - whether voluntary and non-profit, or commercial and for-profit (Lloyd 2013) - and has led to a sharp growth of care services (Evers et al. 2005, p. 197). The largest growth was recorded for corporate providers. The top twenty of them represent eight per cent of nursery places. The British care market is fragmented: 80 per cent of care services are for-profit and provided in roughly equal proportions by private companies and owners of a single facility ('sole traders'). Non-profit and voluntary providers as well as public institutions have a market share of eleven per cent (Moss 2009, p. 8). 
Even when leaving the provision of welfare services largely to market actors, the state nevertheless defines the conditions under which markets should arise and can go as far as adopting a warranty responsibility (Olk 2000, p. 109). In the UK, the legislation requires civic authorities (districts/councils) to guarantee an effective competition between private, voluntary, and independent sector providers in order to provide working parents with childcare. Effective competition initially decreases only the costs of the providers and as such does not secure the standards of educational quality (Moss 2009, p. 16). Standards, such as a national curriculum and certain quality assurance measures, can be part of a strategy of marketization, because they demand the same degree of performance from all providers. After New Labour took over the government in 1997, the policy of marketization did not change, but the content-related priorities were accentuated differently (Lewis 2013; Penn 2007; 2009). Certain measures were promoted in particular, such as an increase in educational quality, and the extension of childcare hours according to common working hours (Belsky et al. 2007; Evers et al. 2005). But if quality standards are too demanding, they can become too expensive for private-sector providers (Michel 2002, p. 334). This represents a dilemma for care policies that rely on marketization strategies.

Marketization is therefore not to be misunderstood as a 'retreat' of the state. It is rather a form of governance, a regulation of the welfare mix. This insight relativises the alleged contrast between marketization and privatization. The concept of the 'welfare mix' allows one to analyse a policy of marketization as a rebalancing of different welfare authorities, a rebalancing that can take different forms, depending on the respective cultural conditions of welfare (for Germany: see Ernst, Mader and Mierendorff, forthcoming).

Care vouchers, such as Luxembourg's chèque-service accueil, create conditions under which public, commercial, and non-profit providers compete for public funds under certain constraints (Evers et al. 2005). The introduction of chèque-service accueil has added a competition element to the subsidiary structure of Luxembourg's care system. It has created a quasi-market of care services, in which the decisions of the users are the provider's condition of existence. On the other hand, the users gain access to the market only because of the state's financial allocations (Evers 2008, p. 50). The private-sector providers of childcare compete with each other and with the conventionalised sector of the care system. They benefit from the increased market power of parents while acquiring in the meantime a dominant position in the extrafamilial care of preschool children. And yet, their economic subsistence always remains at stake. 
The Luxembourg government claims responsibility for setting quality standards in extrafamilial day care. This is directly connected to the granting of agréments or to the contractual service agreements. The standards have become ever more 'educational' in the course of the outlined care-policy development. The regulation (règlements grand-ducaux) of the crèches and foyers de jour from 2001 (see Mémorial 2001), for example, makes demands above all on personnel, infrastructure, hygiene and safety; the 2005 regulation on the maison relais pour enfants (see Mémorial 2005) went further, specifying content-related missions, while the planned Child and Youth Law outlines a national education plan as a benchmark for quality development procedures.

The growth of day care is therefore related to a conceptual change in the Luxembourgian care system that is gradually overcoming the duality of care and education. The starting point was made by the maison relais, which struck a conceptual bridge between school, community, and family. The éducation précoce heralded the tendency to integrate formal education and childcare into Luxembourgian elementary schools. Haag (2012) described it as a hybrid interface between schools and day care. It was introduced in the late 1990s as a free offer to stimulate language development among disadvantaged three-year-olds, more than often from immigrant families. But since the 2009 Education Law, all three-year-olds are entitled to join a précoce class (see Mémorial 2009), making the éducation précoce a regular, but optional pre-primary class. The same Education Law also imposed that municipalities offer after-school care to school-age children (encadrement périscolaire, see Achten 2012, p. 51) and develop plans for cooperation between school and non-school education and care (see Mémorial 2009).

The plan is to continue organising school and non-school education and childcare as a single conceptual framework for the future. A further addition to the ASFT Law from November 2013 replaces the previous types of facilities (crèches, foyers de jour, garderies, and maison relais) by an age-differentiated 'education and care service' (Service d'éducation et d'accueil pour enfants, SEA). The regulation emphasises that out-of-school childcare fulfils an educational mandate (see Mémorial 2013). The draft of the modified Child and Youth Law, as available since 2012 (see Chambre des Députés 2012), includes a national framework plan for non-formal education and commits all 'third sector' providers to implement it through educational concepts for the respective care structures (Concept d'action général). It also determines an evaluation mechanism (Achten 2012, p. 52). Finally, the portfolio for day care, previously part of the Ministry of Family Affairs, was transferred to the Ministry of Education after the national elections in autumn 2013. Luxembourg's education policy makers seek to 
reorganise the sector of integrative care, education, and upbringing between family and school under the banner of 'non-formal education'.

\section{Questions for Further Study}

The history of Luxembourg's childcare system has hardly been researched. The aim of this contribution was to investigate how existing traditions and current decisions interact in the transformation of Luxembourg's childcare system, a transformation that began in the late 1990s and has since gained momentum. Our focus was the marketization of childcare, which, on the one hand, seems inconsistent with Luxembourg's conservative-corporatist welfare state. And yet, the expansion of day care would not have been possible without 'childcare entrepreneurs'.

Our case study reveals a blurring of well-established distinctions and boundaries. This holds true not only for the distinction between the conservative-corporatist and free-market welfare models, i.e. conceptions of 'public' and 'private', but also between education policy and social policy, or in other words education and care. In Luxembourg, the mixed economy of childcare has its equivalent in education policy's 'educare mix', which blurs the boundary between education and care. The influence of European-wide conceptions of child development slowly tips the balance in favour of imbuing Luxembourg's day care with an educational function, despite the traditional distinction between preschool education and childcare. This process has accelerated due to the supra-national impetus of the European Council to restructure welfare with a social investment strategy. The Luxembourg example shows, however, that early childhood care can adopt an informal-education approach in the social investment state (Reyer 2006), and that the latter can develop conceptions of 'educational quality' to accommodate for the child as a carrier of social rights and a citizen-worker of the future (Ostner 2009; Haag 2012).

Admittedly, it remains an open question whether a governance of non-formal education that emphasises the marketization of service provision and the re-positioning of children between family and school can effect an institutional change while relying on a dynamic of heterogeneous expectations for care, multiple standards of 'good childhood', and a diverse care practice as characteristic of the multicultural and multilingual society of Luxembourg. Perhaps the unloved care market Luxembourg wrests itself from political calculations, because it is used by populations that hold other ideals of a 'good childhood' or the responsibilities of the family than have been institutionalised by the publicly funded sector of the care system. Care vouchers give market power to the individual needs of parents. In fact, 
there is evidence that, in Luxembourg, care is segregated along ethnic, linguistic, milieuspecific, and income-related criteria. It is likely that the divergent needs of a multi-cultural society like Luxembourg cannot be integrated into a national framework except in the shape of a market. In that case, the marketization is not only a socio-economic, but also a sociocultural phenomenon, which would lead to considering the cultural context of the care system in the analysis of its mode of operation. This, however, is a mission for further research.

\section{Notes}

1. The typology of the welfare state includes several variants, including the German and Luxembourgian 'social welfare states' (Sozialstaat) (see Kaufmann 2003, p. 16).

2. The average female employment rate in 2013 in the Member States of the EU-28 at 62.5 per cent.

3. For more information about the chèque-service accueil, see http://www.accueilenfant.lu (home page).

4. The billed hours of care for 2009 refer exclusively to the collective facilities.

5. Different prices apply to the different types of facilities. The conventionalised sector has a fixed maximum rate of $€ 7,50$ per child and hour, the non-conventionalised one charges $€ 6$ and childminders $€ 3,50$. The amount not covered by chèque-service accueil must be balanced by parental contributions.

6. The table is based on approved agréments. They grant places for each type of care. Since childminders can accommodate preschool and school children, the table can make no statement about the proportion of the different age classes. We know from the accounting of chèque-service accueil that about a quarter of the time paid to childminders covers non-school-age children (Syndicat Intercommunal de Gestion Informatique 2013).

\section{Bibliography}

M. Achten (2012) 'Von der Tagesbetreuung zur non-formalen Bildung', Forum für Politik, Gesellschaft und Kultur, 322, 50-52.

M. Achten, N. Horn and D. Schronen (2009) 'Kindertageseinrichtungen' in H. Willems et al. (eds.) Handbuch der sozialen und erzieherischen Arbeit in Luxemburg (Luxembourg: éditions saint-paul), vol. 2, 691-707.

M. Achten, C. Baltes-Löhr, L. Deville, M. Lanners, M. Majerus, Y. Oestreicher, A. Ramponi, D. Reuters-Angelsberg and V. Rocha (eds.) (2009) Maison Relais Pour Enfants. Das Handbuch (Luxembourg: Editions Le Phare)

M. Beblavý, A.E. Thum and M. Veselkova (2011) Education Policy and Welfare Regimes in OECD Countries. Social Stratification and Equal Opportunity in Education, CEPS Working Document 357.

J. Belsky, J. Barnes and E. Melhuish (eds.) (2007) The National Evaluation of Sure Start. Does Area-based Early Intervention Work? (Bristol: Policy Press). 
T. Betz (2010) 'Der Kita-Gutschein unter Praxisbedingungen. Eine empirisch-vergleichende Annäherung' in T. Betz, A. Diller and T. Rauschenbach (eds.) Kita-Gutscheine. Ein Konzept zwischen Anspruch und Realisierung (Munich: DJI Verlag), 167-190.

J. Beyer (2006) Pfadabhängigkeit. Über institutionelle Kontinuität, anfällige Stabilität und fundamentalen Wandel (Frankfurt am Main/New York: Campus)

K. J. Brehony and K. Nawrotzki (2011) 'From weak social democracy to hybridized neoliberalism: Early childhood education in Britain since 1945' in C. AllemannGhionda, K. Hagemann and K. H. Jarausch (eds.) Children, families and states: Time policies of childcare, preschool and primary education in Europe (New York/Oxford: Berghahn), 237-256.

M. R. Busemeyer and R. Nikolai (2010) 'Education' in F. G. Castles et al. (eds.) The Oxford Handbook of the Welfare State (Oxford: Oxford University Press), 494-508.

T. Ernst, M. Mader and J. Mierendorff (2014) ,Gewerbliche Anbieter von Kindertagesbetreuung - eine Systematisierung der Trägerlandschaft', Zeitschrift für Soziologie der Erziehung und Sozialisation, forthcoming

G. Esping-Andersen (1990) The Three Worlds of Welfare Capitalism (Cambridge/Princeton: Polity \& Princeton University Press)

G. Esping-Andersen (2002) Why we need a new welfare state (Oxford: Oxford University Press).

G. Esping-Andersen (2002a) 'A child-centered social investment strategy' in G. EspingAndersen (ed.) Why we need a new welfare state (Oxford: Oxford University Press), 26-67.

G. Esping-Andersen (2002b) 'A new gender contract' in G. Esping-Andersen (ed.) Why we need a new welfare state (Oxford: Oxford University Press), 68-95.

A. Evers (2008) 'Wohlfahrtsmix und Governance im Bereich der Kindertagesbetreuung' in A. Diller, M. Heitkötter and T. Rauschenbach (eds.) Familie im Zentrum. Kinderfördernde und elternunterstützende Einrichtungen-aktuelle Entwicklungen und Herausforderungen (Munich: DJI Verlag), 41-67

A. Evers (2011) 'Wohlfahrtsmix im Bereich sozialer Dienste' in A. Evers, R. G. Heinze and T. Olk (eds.) Handbuch Soziale Dienste (Wiesbaden: VS Verlag), 265-283.

A. Evers, J. Lewis and B. Riedel (2005) 'Developing child-care provision in England and Germany: problems of governance', Journal of European Social Policy 15 (3), 195209.

C. Haag (2012) Wandel und Differenzierung von Kindheit als Re-Institutionalisierung. Eine Analyse der Reformpolitik zur Kleinkindbetreuung in Luxemburg, unpublished Ph. D. thesis, Université du Luxembourg.

C. Hartmann-Hirsch (2009) 'Klassifikation des Luxemburgischen Sozialstaates' in H. Willems et al. (eds) Handbuch der sozialen und erzieherischen Arbeit in Luxemburg (Luxembourg: éditions saint-paul), Bd. 2, 275-289. 
C. Hartmann-Hirsch (2010) The State of the Luxembourg's Welfare State: the effects of the Crisis on a Corporatist Model Shifting to a Universalistic Model, Working Paper 201044 (Luxembourg: CEPS/INSTEAD)

M. S. Honig and C. Haag (2012) 'National Childcare in Luxembourg. Taking Stock', in Ministère de la Famille et de l'Integration (ed.) Education and Care for Children in Luxembourg (Luxembourg: Ministère de la Famille), 5-27

F. X. Kaufmann (2003) Varianten des Wohlfahrtsstaats. Der deutsche Sozialstaat im internationalen Vergleich (Frankfurt am Main: Suhrkamp).

N. Kerschen (2009) ,The Welfare System of Luxembourg: From Past Dependency to European Approach', in K. Schubert, S. Hegelich and U. Bazant (eds.) The Handbook of European Welfare Systems (New York: Routledge), 310-327

N. Kneip (2009) 'Tagesfrüherziehung' in H. Willems et al. (eds) Handbuch der sozialen und erzieherischen Arbeit in Luxemburg (Luxembourg: éditions saint-paul), Bd. 2, 709718.

J. Lewis (2013) 'Continuity and change in English childcare policy 1960 - 2000', Social Politics. International Studies in Gender, State and Society 20, 3, 358-386.

R. Lister (2004) 'The Third Way's Social Investment State' in J. Lewis and R. Surender (eds.) Welfare State Change. Towards a Third Way? (Oxford: Oxford University Press), 157181.

E. Lloyd (2013) 'Childcare markets: an Introduction' in E. Lloyd and H. Penn (eds.) Childcare Markets. Can they deliver an equitable service? (Bristol: Polity Press), 3-18.

E. Lloyd and H. Penn (eds.) (2013) Childcare Markets. Can they deliver an equitable service? (Bristol: Polity Press).

M. Majerus (2008) 'Engagement für „Sorgenkinder“. Aufgabe der „Maison Relais pour Enfants" und Kooperation mit der Schule' in D. Schronen and R. Urbé (eds.) Sozialalmanach 2008 (Luxembourg: Confédération Caritas), 289-302.

M. Majerus (2009) 'Ziele der Maison Relais' in M. Achten et al. (eds.) Maison Relais Pour Enfants. Das Handbuch (Luxembourg: Editions Le Phare), 27-35.

C. Martin and B. Le Bihan (2009) 'Public Child Care and Preschools in France: New Policy Paradigm and Path-Dependency' in K. Scheiwe and H. Willekens (eds) Child Care and Preschool Development in Europe. Institutional Perspectives (Basingstoke: Palgrave Macmillan), 57-71.

S. S. Marth and A. Ramponi (2009) 'Außerschulische Kinderbetreuung der Stadt Luxembourg' in H. Willems et al. (eds) Handbuch der sozialen und erzieherischen Arbeit in Luxemburg (Luxembourg: éditions saint-paul), Bd. 2, 699-707.

S. Michel (2002) 'Dilemmas of Child Care' in S. Michael and R. Mahon (eds.) Child Care Policy at the Crossroads. Gender and Welfare State Restructuring (New York/London: Routledge), 333-338. 
P. Moss (2009) There are alternatives! Markets and democratic experimentalism in early childhood education and care, Working Paper No. 53 (The Hague: Bernard van Leer Foundation and Bertelsmann Stiftung).

OECD (ed.) (2011) Starting Strong. Education and Skills (Paris: OECD).

T. Olk (2000) 'Der „aktivierende Staat“. Perspektiven einer lebenslagenbezogenen Sozialpolitik für Kinder, Jugendliche, Frauen und ältere Menschen' in S. Müller et al. (eds.) Soziale Arbeit. Gesellschaftliche Bedingungen und professionelle Perspektiven (Neuwied: Luchterhand), 99-118.

I. Ostner (2009) '„Auf den Anfang kommt es an” - Anmerkungen zur „Europäisierung“ des Aufwachsens kleiner Kinder', Recht der Jugend und des Bildungswesens 57, 1, 4462.

M. Pauly (2011) Geschichte Luxemburgs (Munich: Beck).

H. Penn (2007) 'Childcare Management: how the United Kingdom Government has reshaped its role in developing early childhood education and care', Contemporary Issues in Early Childhood 8, 3, 192-207.

H. Penn (2009) 'Public and Private: the History of Early Education and Care Institutions in the United Kingdom' in K. Scheiwe and H. Willekens (eds) Child Care and Preschool Development in Europe. Institutional Perspectives (Basingstoke: Palgrave Macmillan), 105-125.

H. Penn (2011) 'Gambling on the market: The role of for-profit provision in early childhood education and care', Journal of Early Childhood Research 9, 2, 150-161.

H. Penn (2013) 'Childcare markets: Do they work? ' in E. Lloyd and H. Penn (eds) Childcare Markets. Can they deliver an equitable service? (Bristol: Polity Press), 19-42.

J. Plantenga, C. Remery, M. Siegel and L. Sementini (2008) 'Childcare services in 25 European Union member states: The Barcelona targets revisited' in A. Leira and C. Saraceno (eds) Childhood: Changing contexts (Bingley: Emeral), 27-53.

K. Priem and G. Thyssen (2013) 'Fragmented utopia: Luxembourgian industrialists, intellectual networks and social-educational reforms between tradition and avantgarde', Jahrbuch für Historische Bildungsforschung, 19 (Bad Heilbrunn: Klinkhardt), 106-126.

A. Ramponi (2009) 'Vom Foyer scolaire zur Maison Relais' in M. Achten et al. (eds) Maison Relais Pour Enfants. Das Handbuch (Luxembourg: Editions le Phare), 36-39.

J. Reyer (2006) Einführung in die Geschichte des Kindergartens und der Grundschule (Bad Heilbrunn: Klinkhardt).

K. Scheiwe (2009) 'Bildung und Betreuung in Kindertageseinrichtungen und Vorschulen in Europa', Recht der Jugend und des Bildungswesens 57, 1, 63-77.

K. Scheiwe and H. Willekens (2009) 'Path-dependencies and Change in Child-care and Preschool Institutions in Europe - Historical and Institutional Perspectives' in K. Scheiwe and $\mathrm{H}$. Willekens (eds) Child Care and Preschool Development in Europe. Institutional Perspectives (Basingstoke: Palgrave Macmillan), 1-22. 
W. Streeck and K. Thelen (eds.) (2005) Beyond Continuity. Institutional Change in Advanced Political Economies (Oxford: Oxford University Press).

Syndicat Intercommunal de Gestion Informatique (2014) Abgerechnete Betreuungsstunden für kollektive Strukturen und Tageseltern (Luxembourg).

H. Willekens (2009) 'How and Why Belgium Became a Pioneer of Preschool Development' in K. Scheiwe and H. Willekens (eds) Child Care and Preschool Development in Europe. Institutional Perspectives (Basingstoke: Palgrave Macmillan), 43-56.

H. Willems et al. (eds.) (2009) Handbuch der sozialen und erzieherischen Arbeit in Luxemburg (Luxembourg: éditions saint-paul).

M. Wiltzius and M. S. Honig (2014) Kommerzielle Kinderbetreuung in Luxemburg? Eine Bestandsaufnahme nicht-konventionierter Strukturen der Bildung, Erziehung und Betreuung für Kinder bis zu 12 Jahren (Luxembourg: Ministère de l'Education Nationale), forthcoming.

\section{Data links on the web}

Chambre des Députés (2012) Projet de loi portant modification de la loi du 4 juillet 2008 sur la jeunesse, No. 6410, session ordinaire 2011-12, Luxembourg, http://www.legilux.public.lu/ldp/2012/20120053_I.pdf

Eurostat (2014) Employment rate by sex, http://epp.eurostat.ec.europa.eu, date accessed 16 April 2014

Institut national de la statistique et des études économiques, STATEC (2013) Le Luxembourg en chiffres, http://www.statistiques.public.lu/cataloguepublications/luxembourg-en-chiffres/luxembourg-chiffres.pdf

Inspection générale de la sécurité sociale Luxembourg (2014) Emploi au Luxembourg. Evolution de la population active au Luxembourg,

http://www.isog.public.lu/islux/population-protegee date accessed 23 April 2014

Mémorial, Journal Officiel du Grand-Duché de Luxembourg (1998) Loi du 8 septembre 1998 réglant les relations entre l'Etat et les organismes œuvrant dans les domaines social, familial et thérapeutique, A-No. 82, http://www.legilux.public.lu/leg/a/archives/1998/0082/a082.pdf

Mémorial, Journal Officiel du Grand-Duché de Luxembourg (2001) Règlement grand-ducal du 20 décembre 2001 réglant les relations entre l'Etat et les organismes œuvrant dans les domaines social, familial et thérapeutiques pour ce qui concernent l'agrément gouvernemental à accorder aux gestionnaires de structures d'accueil sans hébergement pour enfants, A-No. 159, http://www.legilux.public.lu/leg/a/archives/2001/0159/

Mémorial, Journal Officiel du Grand-Duché de Luxembourg (2005) Règlement grand-ducal du 20 juillet 2005 concernant l'agrément à accorder aux gestionnaires de maison relais pour enfants, A-No. 123, 2146,

http://www.legilux.public.lu/leg/a/archives/2005/0123/

Mémorial, Journal Officiel du Grand-Duché de Luxembourg (2007) Loi du 30 novembre 2007 portant règlementation de l'activité d'assistance parentale, A-No. 214, http://www.legilux.public.lu/leg/a/archives/2007/0214/a214.pdf 
Mémorial, Journal Officiel du Grand-Duché de Luxembourg (2009a) Règlement grand-ducal du 13 février 2009 instituant le «chèque-service accueil», A-No. 26, 376, http://www.legilux.public.lu/leg/a/archives/2009/0026/

Mémorial, Journal Officiel du Grand-Duché de Luxembourg (2009) Loi du 6 février 2009 portant organisation de l'enseignement fondamental, A-No 20, 200, section 6 l'encadrement périscolaire,

http://www.legilux.public.lu/leg/a/archives/2009/0020/a020.pdf

Mémorial, Journal Officiel du Grand-Duché de Luxembourg (2013) Règlement grand-ducal du 14 novembre 2013 concernant l'agrément à accorder aux gestionnaires de services d'éducation et d'accueil pour enfants, A-No. 199, 3702, http://www.legilux.public.lu/leg/a/archives/2013/0199/a199.pdf

Ministère de la Famille et de l'Intégration Luxembourg (2010) Rapport d'activité 2009, http://www.mfi.public.lu/publications/01_rapports-activite/rapp_act_2009.pdf

Ministère de la Famille et de l'Intégration Luxembourg (2011) Rapport d'activité 2010, http://www.mfi.public.lu/publications/01_rapports-activite/rapp_act_2011.pdf

Ministère de la Famille et de l'Intégration Luxembourg (2012) Rapport d'activité 2011, http://www.mfi.public.lu/publications/01_rapports-activite/rapp_act_2011.pdf

Ministère de la Famille et de l'Intégration Luxembourg (2013) Rapport d'activité 2012, http://www.mfi.public.lu/publications/01_rapports-activite/rapp_act_2012.pdf

Ministère de la Famille et de l'Intégration Luxembourg (2014) Rapport d'activité 2013, http://www.mfi.public.lu/publications/01_rapports-activite/rapp_act_2013.pdf 